\title{
Relecturas martianas de Rolando Rodríguez
}

\author{
Re-readings of Martí by Rolando Rodríguez
}

\author{
Mauricio Núñez Rodríguez \\ Centro de Estudios Martianos de La Habana \\ Cuba
}

El análisis profundo a partir de fuentes primarias caracteriza el volumen Dos Ríos a caballo y con el sol en la frente $\mathbf{1}$ del historiador cubano Rolando Rodríguez, una de las figuras a quien estuvo dedicada la XXIII edición de la Feria Internacional del Libro de La Habana del año 2013.

A través del viaje por el amplio universo sociocultural e histórico que el autor nos brinda conoceremos de la significación de importantes hallazgos para la historia de Cuba e Hispanoamérica en torno a los documentos que José Martí llevaba consigo en la hora final de Dos Ríos y, a su vez, estas páginas desentrañan aristas polémicas o poco conocidas de las últimas horas de su vida.

La información que conforma este libro -ilustrado a partir de una obra del artista cubano Carlos Enrique- anteriormente fue conocida a través de dos entregas: Dos Ríos a caballo y con el sol en la frente (Ciencias Sociales, La Habana, 2002) y Martí: los documentos de Dos Ríos (Sed de Belleza, Santa Clara, 2001). Ahora el lector tendrá la posibilidad de conocer, en un solo texto, toda la información e investigación resultantes de la estancia del autor en el Archivo Central del Instituto de Histo-

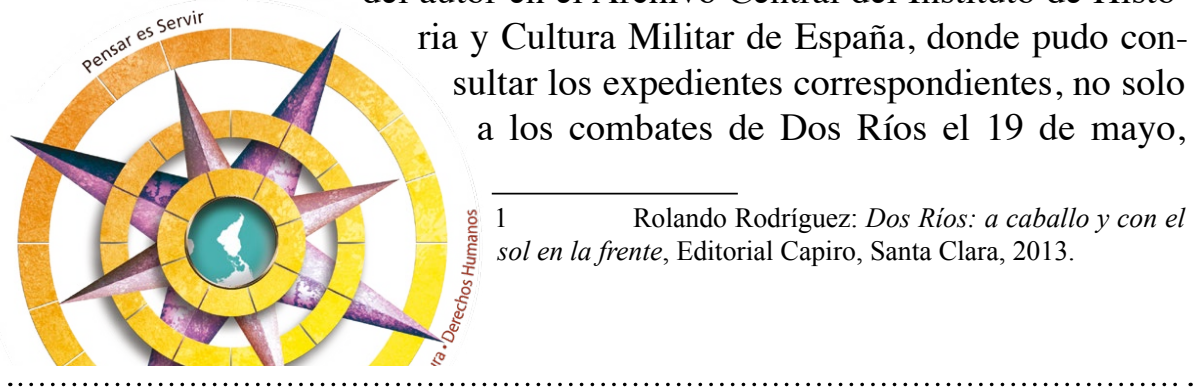


sino también a los ocurridos entre los días 23 y 26 de ese mes.

El discurso ensayístico del texto demuestra un amplio dominio de la lengua española por parte de autor, al utilizar un amplio registro, tanto de las expresiones más cultas y académicas como de aquellas del uso más coloquial; y resulta que, en ocasiones, necesita transmitir ciertos colores del diálogo, de las escenas o del temperamento y personalidad de los héroes que son los protagonistas de la historia que necesita sustantivar verbos o crear giros o intensiones comunicativas inusuales que le permitan dibujar los múltiples y complejos matices de contextos colmados de tensiones socioculturales e históricas.

Rolando Rodríguez es un hombre de énfasis al decir y esas intenciones están en el discurso ensayístico de esta entrega en la que aparece ante el lector, unas veces el agudo analista, mientras que, en otras, el narrador de amplios registros escriturales que utiliza la palabra como laboratorio de comunicación. Su peculiar y enfático uso de las comas es directamente proporcional a su decir sentencioso.

La información aquí reunida sirvió como fuente bibliográfica al documental Dos Ríos: el enigma, del realizador Roly Peña que ha sido presentado en la televisión cubana en varias ocasiones y es que el estilo narrativo del autor el presentar, valorar y novelar los hechos históricos que centralizan su estudio, logra largas secuencias cinematográficas que motivan y facilitan la lectura y comprensión del recorrido de José Martí, los últimos días de su vida hasta la hora fatídica de Dos Ríos.

Cada una de las escenas que el autor reconstruye están concatenadas entre sí a partir de una amplia utilización de fuentes primarias, testimonios, diarios o estudios de otros investigadores que brindan al análisis una gran riqueza de criterios sobre acontecimientos trascendentales para la historia de Cuba acaecidos en la zona de convergencia de los ríos Cauto y Contramestre, el 19 de mayo de 1895 .

Pero este análisis integral y concatenado de los hechos origina en el discurso largas secuencias cinematográficas en las que el autor logra tal complicidad en los hechos que olvida la existencia de los puntos y seguido o de los puntos y aparte, $y$ es que realmente, en ocasiones, no le hacen mucha falta porque sus amplias descripciones pletóricas

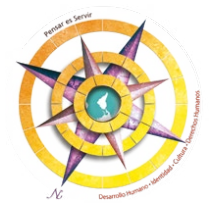


de detalles e informaciones contextuales no deben ser interrumpidas sino que la expresión es solucionada con largas oraciones subordinadas que se encadenan entre sí, de manera escalonada y en cascada que por su frecuencia y efectividad narrativa, en este caso, forman parte del estilo del autor.

Los documentos que José Martí llevaba consigo en la hora final de Dos Ríos no solo permiten acercarnos al mundo íntimo del héroe, las cartas de los más cercanos y queridos y para ellos, y aquellas informaciones destinadas a estrategias militares, pero también son expresión de su inexperiencia combativa, pues se supone que un soldado marche a la batalla ligero o con los atavíos propios, necesarios e imprescindibles de una contienda y no con la papelería que se muestra en el capítulo VI, la cual, poco o nada, le hubiera servido en un enfrentamiento con el enemigo. No solo la papelería encontrada, sino también: dinero. Como expresa Rolando Rodríguez, poéticamente, la correspondencia con sus seres queridos, que llevaba consigo, le servía de amuleto.

Esos documentos permiten adentrarnos en las preocupaciones más cercanas que "bullían" en el universo del héroe en ese minuto. Siempre hallazgos como este son reveladores, pues brindan precisiones únicas más allá de valoraciones o conjeturas.

Estas páginas constituyen una valoración novelada de un grupo de acontecimientos cenitales, dudas y enigmas que más de un siglo después continúan convocando a estudiosos cubanos y a las nuevas generaciones de lectores que, desde su perspectiva, se acercan a nuestra historia. 